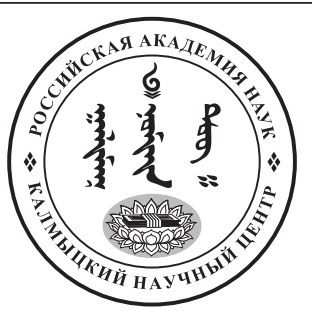

Published in the Russian Federation

Oriental Studies (Previous Name: Bulletin of the Kalmyk Institute

for Humanities of the Russian Academy of Sciences)

Has been issued as a journal since 2008

ISSN: 2619-0990; E-ISSN: 2619-1008

Vol. 13, Is. 2, pp. 318-329, 2020

DOI: $10.22162 / 2619-0990-2020-48-2-318-329$

Journal homepage: https://kigiran.elpub.ru

УДК 93/352

\title{
Территориальный спор по поводу Сарпинского и Степного районов между Астраханской, Сталинградской областями и Ставропольским краем в 1954 г.
}

\author{
Евгений Федорович Кринко \\ ${ }^{1}$ Калмыцкий научный центр РАН \\ (д. 8, ул. И. К. Илишкина, 358000 Элиста, Российская Федерация) \\ доктор исторических наук, ведущий научный сотрудник \\ iD 0000-0003-3008-5626. E-mail: krinkoef@gmail.com
}

\begin{abstract}
Аннотация. Введение. Этнические депортации в СССР привели к ликвидации ряда национальных автономий и передаче их территорий другим национально-государственным и административно-территориальным образованиям. Территория Калмыцкой АССР была разделена между Астраханской, Сталинградской, Ростовской областями и Ставропольским краем. История данных территорий в период пребывания калмыков в ссылке недостаточно исследована в современной историографии. К неизученным вопросам относится и территориальный спор между Астраханской областью, Ставропольским краем и Сталинградской областью в 1954 г. по поводу Сарпинского и Степного районов. Материаль $u$ методы. Статья основана на впервые вводимых в научный оборот документах фонда Бюро ЦК КПСС по РСФСР в Российском государственном архиве социально-политической истории. Автор также использовал и другие исторические и историографические источники. В работе с источниками применялись сравнительно-исторический, проблемно-хронологический методы и метод источниковедческой критики. Результаты. Разногласия по поводу Сарпинского и Степного районов - пример территориальных споров между разными краями, областями и республиками СССР. Общие причины данных конфликтов связаны с административнотерриториальными преобразованиями в советский период истории. В то же время конкретные причины отдельных территориальных споров отличаются. Обострение территориальных претензий между республиками, краями и областями на юге страны произошло после смерти И. В. Сталина и смены политического руководства страны. Астраханские руководители были недовольны передачей в 1952 г. Степновского района в Ставропольский край, где он был переименован в Степной. Они обратились к высшему партийному и советскому руководству с просьбой передать им не только данный район из Ставропольского края, но и Сарпинский район из Сталинградской области. Но советское руководство в 1953-1955 гг. проявляло осторожность в вопросах об изменении административных границ. Позиции ставропольского и сталинградского руководства оказались лучше обоснованы, и астраханские руководители
\end{abstract}


не смогли добиться поставленных задач. После возвращения калмыков из ссылки в 1957 г. Сарпинский и Степной район вошли в состав калмыцкой национальной автономии.

Ключевые слова: Калмыкия, Астраханская область, Сарпинский район, Степной (Степновский) район, Сталинградская область, Ставропольский край, административно-территориальные преобразования

Благодарность. Исследование проведено в рамках государственной субсидии - проект «Комплексное исследование процессов общественно-политического и культурного развития народов Юга России» (номер госрегистрации: АААА-А19-119011490038-5).

Для цитирования: Кринко Е. Ф. Территориальный спор по поводу Сарпинского и Степного районов между Астраханской, Сталинградской областями и Ставропольским краем в 1954 г. // Oriental Studies. 2020. T. 13. № 2. C. 318-329. DOI: 10.22162/2619-0990-2020-48-2-318-329

\title{
Astrakhan Oblast, Stavropol Krai and Stalingrad Oblast: 1954 Territorial Dispute over Sarpinsky and Stepnoy Districts
}

\author{
Evgeny F. Krinko ${ }^{1}$ \\ ${ }^{1}$ Kalmyk Scientific Center of the RAS \\ (8, Ilishkin St., Elista 358000, Russian Federation) \\ Dr. Sc. (History), Leading Research Associate \\ (iD)0000-0003-3008-5626. E-mail: krinkoef@gmail.com
}

\begin{abstract}
Introduction. Ethnic deportations in the USSR led to the elimination of a number of national autonomies and annexation of their territories to other regions. After the abolishment the Kalmyk ASSR, its lands were divided between Astrakhan, Stalingrad, Rostov Oblasts and Stavropol Krai. The history of these territories during the Kalmyk deportation remains essentially understudied. One such unexplored issue is the 1954 territorial dispute over Sarpinsky and Stepnoy Districts between Astrakhan Oblast, Stavropol Krai and Stalingrad Oblast. Materials and Methods. The article introduces and analyzes documents contained in the Collection of the CSPU Central Committee (RSFSR), Russian State Archive of Socio-Political History. The study also involves other historical and historiographic sources discovered by the author, employing the comparative-historical, problem-chronological methods, and that of source criticism. Results. The disagreements over Sarpinsky and Stepnoy Districts are an example of territorial disputes between different national-state and administrativeterritorial entities in the USSR. Common causes of the conflicts were Soviet administrative and territorial transformations. At the same time, actual specific reasons for individual territorial disputes do differ. Territorial claims between southern regions escalated after J. Stalin's death and subsequent change in the country's political leadership. Astrakhan executives were dissatisfied with the 1952 transfer of Stepnovsky District to Stavropol Krai. They appealed to the party establishment and Soviet leaders proper reclaiming territories of Stepnoy (Stepnovsky) District (Stavropol Krai) and Sarpinsky District (Stalingrad Oblast). But in 1953 to 1955, the Soviet leadership was hesitant enough to alter any administrative boundaries. Moreover, positions of Stavropol and Stalingrad executives in this dispute proved well-justified. So, the dispute lead to nothing, and after the return of Kalmyks in 1957 Sarpinsky and Stepnoy Districts became parts of the Kalmyk national autonomy.
\end{abstract}

Keywords: Kalmykia, Astrakhan Oblast, Sarpinsky District, Stepnovsky (Stepnoy) District, Stalingrad Oblast, Stavropol Krai, administrative-territorial transformations

Acknowledgments: The reported study was funded by government subsidy — project name 'SocioPolitical and Cultural Development of South Russia's Peoples: a Comprehensive Research of Respective Processes' (state reg. no. AAAA-A19-119011490038-5).

For citation: Krinko E. F. Astrakhan Oblast, Stavropol Krai and Stalingrad Oblast: 1954 Territorial Dispute over Sarpinsky and Stepnoy Districts. Oriental Studies. 2020; Vol. 13(2): 318-329 (In Russ.). DOI: $10.22162 / 2619-0990-2020-48-2-318-329$ 


\section{Введение}

Проблемы принудительных переселений народов СССР в годы Великой Отечественной войны и их последствий широко разрабатываются современными исследователями (см. подробнее: [Степанов 2010; Кропачев, Кринко 2019: 174-247; и др.]).

Обращение к данной теме, как правило, сводится к анализу драматических обстоятельств выселения, пребывания репрессированных народов в местах принудительной ссылки и их последующего непростого возвращения на родину в связи с реабилитацией. В значительно меньшей степени изучена история территорий упраздненных национальных автономий в период, когда они были включены в состав других административно-территориальных образований. Еще в конце 1960-х - начале 1970-х гг. в восстановленных (Калмыцкая АССР, Чечено-Ингушская АССР) и преобразованных (Кабардино-Балкарская АССР Карачаево-Черкесская автономная область) национальных автономиях вышли обобщающие исторические труды [История Кабардино-Балкарской 1967; Очерки истории Калмыцкой 1970; Очерки истории Карачаево-Черкесии 1972; Очерки истории Чечено-Ингушской 1972].

В них рассматривались вопросы истории данных регионов в конце войны и в первое послевоенное десятилетие. Однако по идеологическим соображениям многие проблемы и противоречия в их развитии в те годы замалчивались. Современные исследователи истории депортированных народов и их национально-государственных образований обоснованно отмечают негативные последствия принудительных переселений для социально-экономического развития данных территорий [История Чечни 2008: 559-561; История Калмыкии 2009: 587-588; и др.]. Но многие вопросы их истории в 1943-1957 гг. все еще находятся за пределами внимания исследователей.

Указанные тенденции отчетливо прослеживаются при обращении к истории территорий бывшей Калмыцкой АССР. По указу Президиума Верховного Совета
СССР от 27 декабря 1943 г. «О ликвидации Калмыцкой АССР и образовании Астраханской области в составе РСФСР» они были разделены между несколькими административно-территориальными образованиями. Большая часть - Долбанский, Кетченеровский, Лаганский, Приволжский, Троицкий, Уланхольский, Черноземельский, Юстинский районы и г. Элиста - были включены в состав образованной по тому же указу Астраханской области. В нее также вошли г. Астрахань, Владимировский, Володарский, Енотаевский, Икрянинский, Камызякский, Красноярский, Наримановский и Харабалинский районы бывшего Астраханского округа Сталинградской (в настоящее время - Волгоградской) области. Малодербетовский и Сарпинский районы вошли в состав Сталинградской области, Западный и Яшалтинский - Ростовской области, Приютинский ${ }^{1}$ - Ставропольского края [Государственное строительство 2009: 286].

Административно-территориальные преобразования на данных территориях нашли отражение лишь в подготовленных архивами справочных изданиях [Территориальные преобразования 1976; Астраханская область 1984; Калмыцкая АССР 1984; История административно-территориального 2009], что позволяет считать их недостаточно изученными. Своеобразными «белыми пятнами» остаются и связанные с ними территориальные споры и разногласия. Такой спор возник в мае 1954 г. между Астраханской областью, с одной стороны, Ставропольским краем и Сталинградской областью, с другой стороны, по поводу Сарпинского и Степного районов.

\section{Материалы и методы}

В работе использовались различные исторические и историографические источники. В первую очередь, это делопроизводственные документы, выявленные в Российском государственном архиве социально-политической истории (далее - РГАСПИ), впервые вводимые в

1 Приютинский улус образован в 1938 г. После восстановления автономии Калмыкии в 1957-1958 гг. создан Приютненский район. 
научный оборот. Среди них докладная записка руководителей Астраханской области, подписанная первым секретарем обкома КПСС И. П. Ганенко и председателем исполкома Совета депутатов трудящихся П. С. Кузьминым. На ней стоят дата отправки и исходящий номер, штамп о получении в ЦК КПСС с соответствующей датой и указанием «Подлежит возврату в Общий отдел ЦК КПСС» [РГАСПИ. Ф. 556. Оп. 14. Д. 11. Л. 7-9]. Подписи подлинные, но какие-либо резолюции или пометы отсутствуют. На справке об экономической целесообразности оставления Степного района в административных границах Ставропольского края подписи ответственного за ее подготовку секретаря Ставропольского крайкома КПСС А. И. Васькова нет. Указаны фамилии технических сотрудников, обеспечивших передачу и получение документа в ЦК КПСС, и дата. Внизу стоит подпись неизвестного лица [РГАСПИ. Ф. 556. Оп. 14. Д. 11. Л. 1013]. Справка, подписанная начальником Главного управления животноводства и ветеринарии, членом коллегии Министерства сельского хозяйства РСФСР П. Есауловым, даты не имеет [РГАСПИ. Ф. 556. Оп. 14. Д. 11. Л. 14-15]. Записка ответственных сотрудников ЦК КПСС Е. И. Громова и В. П. Мыларщикова имеет дату и резолюцию на первой странице [РГАСПИ. Ф. 556. Оп. 14. Д. 11. Л. 16-18].

Все указанные документы обнаружены в фонде Бюро ЦК КПСС по РСФСР, хотя данный орган был создан только в 1956 г. Вероятно, до этого они хранились в общем отделе ЦК КПСС и были переданы из него с созданием специальной инстанции, призванной руководить работой республиканских и региональных партийных, советских и хозяйственных органов и организаций в РСФСР.

Помимо этого, использовался ряд документов из фонда Волгоградского областного управления статистики Центрального статистического управления при Совете Министров РСФСР в Государственном архиве Волгоградской области. Они позволили проследить переименования населенных пунктов Сарпинского района [ГАВО. Ф. Р-686. Оп. 5. Д. 163. Оп. 11. Д. 252]. Ряд сведений по административно-территориальным преобразованиям и переименованиям населенных пунктов рассматривае- мых районов был извлечен из справочных изданий [РСФСР 1947; РСФСР 1955; Территориальные преобразования 1976; Государственное строительство 2009; и др.]. Для установления должностей и биографических сведений упоминавшихся в документах лиц использовались материалы «Справочника по истории Коммунистической партии и Советского Союза 1898-1991» [Справочник по истории].

Статья написана на основе принципа историзма, обусловившего изучение разногласий по поводу Сарпинского и Степного районов между Астраханской, Сталинградской областями и Ставропольским краем в контексте определенного исторического времени и в их развитии, а также системного подхода. При анализе источников применялись сравнительно-исторический и проблемно-хронологический методы, а также метод источниковедческой критики документов.

\section{Основная часть}

Перекройка административно-территориальной структуры на уровне сельских советов продолжалась на протяжении всего рассматриваемого периода. Населенные пункты неоднократно меняли свою административную принадлежность, сельские советы периодически объединялись, затем снова разукрупнялись. Эти процессы сопровождались переименованием многих населенных пунктов, сельских советов и районов, особенно в первое время после депортации, что нередко было связано с отказом от калмыцких топонимов. Так, в Сарпинском районе к концу Великой Отечественной войны поселок Аршань-Зельмень был переименован в хутор Орошаемый, поселок Аршань-Годжур - в хутор Песчаный, хутор Догзмакин — в хутор Дальний, село Кенкря - в хутор Коллективный. Изменялись и топонимы некалмыцкого происхождения: хутор Баланов назвали Степным, хутор Жарков - Кировским, хутор Коробкин - Молотовским, хутор Совин - Вишневским, хутор Толочкин - Красноармейским, село Уманцево - хутором Первомайским [ГАВО. Ф. Р-686. Оп. 5. Д. 163. Л. 120].

Но ряд новых названий не прижился, и с 1947 г. хутор Первомайский снова стал Уманцевским [РСФСР 1947: 325], а с 1948 г. - селом Уманцево. Были воз- 
вращены прежние названия поселкам Аршань-Годжур и Аршань-Зельмень, селу Кенкря, хуторам Баланову, Жаркову, Коробкину, Совину [ГАВО. Ф. Р-686. Оп. 11. Д. 252. Л. 54].

Изменения на уровне районов происходили не так часто, но имели более весомое значение для административной структуры региона. В 1950 г. был ликвидирован Малодербетовский район Сталинградской области, а его территория вошла в состав Сарпинского района. В связи с переименованием Элисты, ставшей административным центром Троицкого района, он также получил название Степновского. В декабре 1944 г. село Эсто-Хагинка, ставшее центром Яшалтинского района, было переименовано в Степное [Территориальные преобразования 1976: 268]. Соответственно, и этот район Ростовской области стал называться Степновским. В Ставропольском крае в это время уже существовал Степновский район с центром в селе Степном. В результате три района с одинаковым названием Степновских существовали одновременно в соседних регионах - Астраханской, Ростовской областях и Ставропольском крае.

14 января 1952 г. Степновский район Астраханской области был передан в административное подчинение Ставропольского края. При этом во избежание путаницы он был переименован в Степной район. Передача Степновского района вряд ли была согласована с руководством Астраханской областью и вызвала его недовольство. Однако высказать его оно решилось уже после смерти И. В. Сталина при новом советском партийном и государственном руководстве.

10 мая 1954 г. первый секретарь Астраханского обкома КПСС И. П. Ганенко и председатель Астраханского областного исполкома Совета депутатов трудящихся П. С. Кузьмин направили письмо председателю Совета Министров СССР Г. М. Маленкову и первому секретарю ЦК КПСС Н. С. Хрущеву, в котором просили «рассмотреть и решить вопрос о возвращении в состав Астраханской области Сарпинского и Степновского животноводческих районов, восстановив таким образом возможность нормальной эксплоатации ${ }^{2}$ пастбищных и сенокосных угодий прикаспийской низмен-

\footnotetext{
${ }^{2}$ Орфография сохранена.
}

ности в интересах дальнейшего развития тонкорунного овцеводства». В ЦК КПСС документ, судя по штампу, был получен 13 мая [РГАСПИ. Ф. 556. Оп. 14. Д. 11. Л. 7].

Обращает на себя внимание то, что в письме говорится о возвращении не только Степновского района, который, действительно, входил в Астраханскую область с 1944 по 1952 гг. (показательно, что использовалось его прежнее, а не новое название), но и Сарпинского, ранее не находившегося ни в ее составе, ни в составе Астраханского округа, на основе которого она была создана. О возвращении в административном отношении можно было бы вести речь, если бы существовала правопреемственность Астраханской области с Калмыцкой АССР. Но такая правопреемственность между ними, разумеется, отсутствовала. Очевидно, что о возвращении районов говорилось совершенно в другом значении, которое раскрывается ниже.

Астраханские руководители характеризовали пастбищные и сенокосные угодья прикаспийской низменности как единый животноводческий район, «в центре которого находятся зимние пастбища, в состав которых входят „черные земли““3, а на западе и севере расположены по преимуществу летние пастбища и в небольшом количестве сенокосные угодья, используемые для создания части страховых запасов сена. На востоке описываемого района расположена Волго-Ахтубинская пойма, естественные сенокосы которой и сеяные травы дают возможность в достатке обеспечить растущее поголовье овец кормами в зимний период» [РГАСПИ. Ф. 556. ОП. 14. Д. 11. Л. 7].

В письме подчеркивалось, что «целостность нижневолжского животноводческого района была нарушена» тем, что в 1943 г. «северная часть пастбищных и сенокосных угодий была влита в состав Сталинградской области, на территории этих земель создан Сарпинский район». Далее, в 1952 г. «западная часть земель, входящая в административные границы Степновского района, была передана Ставропольскому краю» [РГАСПИ. Ф. 556. Оп. 14. Д. 11. Л. 8].

Территориальные преобразования, против которых выступали астраханские ру-

3 Так в документе. Имеется в виду часть Прикаспийской низменности. 
ководители, излагались в письме неточно, а то и ошибочно. Главное внимание уделялось не принятым административным решениям, а их негативным хозяйственным последствиям, преодолеть которые и было призвано «возвращение» двух районов в состав Астраханской области. В письме отмечалось, что Сарпинский и Степновский районы «по-прежнему используют ,черные земли“, входящие в состав Астраханской области», а их пребывание «в административных границах Сталинградской области и Ставропольского края ослабляет возможность планомерного и рационального использования пастбищ и сенокосов, затрудняет работы по строительству, благоустройству и обводнению этих земель, а также отрывает животноводство Сарпинского и Степновского районов от кормовых ресурсов Волго-Ахтубинской поймы и дельты Волги» [РГАСПИ. Ф. 556. Оп. 14. Д. 11. Л. 8-9]. Говорилось о возможности и необходимости «крупно увеличить количество тонкорунных овец, отгоняемых на зимние пастбища» в прикаспийской низменности. Однако существовавший порядок использования «черных земель» с обеспечением поголовья зимой кормами за счет скашивания трав на большой части пастбищ вел к резкому снижению их продуктивности и «дальнейшему ухудшению их сельскохозяйственного использования» [РГАСПИ. Ф. 556. Оп. 14. Д. 11. Л. 7-8]. С ростом поголовья овец, по мнению астраханских руководителей, возрастала «необходимость использования кормовых ресурсов Волго-Ахтубинской поймы и дельты Волги, без чего невозможно рационально использовать степные пастбища. В условиях засушливого климата Нижнего Поволжья сенокосы на заливных лугах и сеяные травы на поливных землях Волго-Ахтубинской поймы и дельты Волги дают высокие и устойчивые урожаи независимо от климатических условий» [РГАСПИ. Ф. 556. Оп. 14. Д. 11. Л. 8].

В завершении письма речь шла уже только о Степновском районе, который «до передачи его в состав Ставропольского края служил рассадником племенных тонкорунных овец для описываемого животноводческого района». По мнению авторов письма, «экономически Степновский район, как и прежде, тяготеет к Астрахани», а его возвращение создавало возможность восстано- вить существовавшие до перехода в Ставропольский край животноводческие совхозы «Прикумский», «Состинский», «Краснинский» ${ }^{4}$, «Гашунский», «Песчаный», «Южный» и «Сайгачный» [РГАСПИ. Ф. 556. Оп. 14. Д. 11. Л. 9].

Однако руководители Ставропольского края и Сталинградской области выступили против передачи в Астраханскую область рассматриваемых районов. Уже 20 мая 1954 г. второй секретарь Ставропольского крайкома КПСС А. И. Васьков направил в ЦК КПСС справку об экономической целесообразности оставления Степного района в административных границах Ставропольского края. В ней ожидаемо указывалось, что передача территории произошла «по ходатайству колхозников, рабочих и служащих района, руководителей Степного района» и обуславливалась «необходимостью приближения административного руководства», улучшения снабжения совхозов, машинно-тракторных станций (МТС) и колхозов и «наиболее рациональным использованием громадных земельных площадей, которыми располагали колхозы и совхозы Степного района» [РГАСПИ. Ф. 556. Оп. 14. Д. 11. Л. 10]. Кроме этого, необходимость передачи Степного района в Ставропольский край обуславливалась «хорошими условиями для развития тонкорунного овцеводства в колхозах и совхозах этого района» [РГАСПИ. Ф. 556. Оп. 14. Д. 11. Л. 10].

Наряду с общими утверждениями справка А. И. Васькова содержала значительное количество конкретных цифр и фактов, что придавало ей намного более аргументированный характер по сравнению с письмом астраханских руководителей. Он писал, что в момент передачи Степного района в административное подчинение Ставропольского края из Астраханской области тот имел в своем составе 6 колхозов, 15 совхозов, 2 МТС, 1 машинно-животноводческую станцию (МЖС), 5 лесозащитных станций [РГАСПИ. Ф. 556. ОП. 14. Д. 11. Л. 10]. В колхозах к 1 января 1952 г. насчитывалось 11,5 тыс. голов крупного рогатого скота, 160 тыс. овец и коз, 953 свиньи, 1323 лошади и 17,5 тыс. голов птицы. Совхозы района имели 28170 голов крупного рогатого скота, 81127 овец, 1703 лошади и 845 сви-

\footnotetext{
${ }^{4}$ Так в документе.
} 
ней. Далее указывалось, что Степной район всего за два года стал «одним из крупных сельскохозяйственных районов края», имея в своем составе 6 колхозов, 11 совхозов, 2 МТС, 5 МЖС и 1 механизированный лесхоз. За 1952-1953 гг. поголовье скота в колхозах Степного района существенно увеличилось: крупного рогатого скота на 981 голов, или на 8,5 \%, овец и коз - на 63 тыс. голов, или на $40 \%$, свиней — на 280 голов, или на $30,2 \%$, лошадей - на 841 голову, или на 48,4 \%, и птицы - на 5832 голов, или на $33,2 \%$. К 1 октября 1953 г. колхозы Степного района имели 12,5 тыс. голов крупного рогатого скота, 224 тыс. голов овец, 1214 голов свиней, 1964 лошади и 23383 птицы [РГАСПИ. Ф. 556. Оп. 14. Д. 11. Л. 10-11].

В справке подчеркивалась роль руководства Ставропольского края в развитии материальной базы колхозов Степного района: «Имея целью создание на территории Степного района значительной базы для развития тонкорунного овцеводства, крайком партии, крайисполком добились передачи колхозам края во временное пользование 300 тыс. гектаров земли ликвидированных совхозов на территории Степного района. За 1952-1953 гг. на этой площади колхозы создали соответствующую материальную базу для дальнейшего развития тонкорунного овцеводства»: здесь были построены 49 кошар, 88 базов, 18 навесов, 107 чабанских домиков, вырыты 110 шахтных колодцев. В 1953-1954 гг. на этих участках зимовали 148 тыс. овец. Дальнейшие перспективы в развитии тонкорунного овцеводства в колхозах Степного района связывались с передачей по решению советского правительства 300 тыс. гектаров «в вечное пользование колхозов края. Это даст возможность 11 районам края зимовать овец на этих пастбищах, увеличить поголовье тонкорунных овец до 300 тыс. голов из расчета 1 овцы на 1 гектар» [РГАСПИ. Ф. 556. Оп. 14. Д. 11. Л. 11]. Отмечалась значительная работа «по укреплению кадрами колхозов, МТС и МЖС Степного района». После решений сентябрьского Пленума ЦК КПСС сюда были направлены 53 специалиста с высшим и средним образованием [РГАСПИ. Ф. 556. Оп. 14. Д. 11. Л. 11].

Не меньше внимания уделялось и развитию совхозов Степного района. При этом подчеркивалось, что в Астраханской области они «нерационально использовали земельные территории и природные условия»: 9 совхозов занимались разведением мясного скота, 5 - каракульских овец, и только один имел тонкорунное овцеводство. В составе Ставропольского края 9 из 11 совхозов были «переведены на овцеводческое направление с разведением тонкорунных овец, и решается вопрос о смене направления хозяйства остальных двух совхоЗов» [РГАСПИ. Ф. 556. ОП. 14. Д. 11. Л. 11].

В целях экономического укрепления совхозов, создания необходимых культурно-бытовых и производственных условий труда и жизни трест овцесовхозов в 19521953 гг. обеспечил капитальное строительство 146 жилых домов, 2 электростанций, 67 кошар, 22 скотных дворов, 200 шахтных колодцев, 5 прудов и других построек на общую сумму в 21,1 млн руб. В 1954 г. совхозы Степного района должны были построить еще 196 жилых домов, 2 школы, 1 механизаторскую, 34 кошары, 22 скотных двора, 101 шахтный колодец, 7 прудов на сумму более 24,3 млн руб. [РГАСПИ. Ф. 556. Оп. 14. Д. 11. Л. 11-12].

В справке отмечалось, что к 1 октября 1953 г. совхозы Степного района имели 157,6 тыс. голов овец, или на 94,2 \% больше по сравнению с 1 января 1952 г., 48,9 тыс. голов крупного рогатого скота - больше на 73,7 \%, 3674 лошадей, или на 115,7 \% больше, чем на 1 января 1951 г. Значительно возросла сдача продуктов животноводства. Так, в 1953 г. было сдано 4383 центнеров шерсти, или на 52,5 \% больше, мяса 51,514 центнеров, или на 264,6 \% больше, чем в 1951 г. Значительно расширились и посевные площади: в текущем году предполагалось посеять 21360 гектаров, или на 104,4 \% больше, чем в 1951 г. С целью дальнейшего расширения посевных площадей под зерновые и кормовые культуры совхозы распахали 58 тыс. гектаров целинных и залежных земель.

Еще одним важным направлением считалась работа по оснащению совхозов техникой. За 1952-1953 гг. им было выделено 65 тракторов, 40 грузовых автомашин, 5 бензовозов, 5 легковых автомашин, 5 комбайнов, 2 походных автомастерских. Для дальнейшего пополнения машинно-тракторного парка совхозов в 1954 г. выделя- 
лось 39 тракторов, 95 сеялок, 40 плугов, 15 культиваторов и других сельскохозяйственных машин. За два года для укрепления совхозов руководящими работниками и специалистами в них были направлены на работу 131 чел., из них 21 чел. с высшим образованием и 78 - со средним образованием, послано на постоянную работу 552 механизатора, подготовлено 70 трактористов и комбайнеров в школах механизации и 54 машиниста самоходных сенокосилок на курсах при совхозах. В целях повышения квалификации курсовую подготовку при сельскохозяйственных институтах и техникумах прошли 19 представителей руководящего состава совхозов [РГАСПИ. Ф. 556. Оп. 14. Д. 11. Л. 12].

В результате принятых мер, по оценке А. И. Васькова, совхозы Степного района за истекшие два года «экономически значительно окрепли» [РГАСПИ. Ф. 556. Оп. 14. Д. 11. Л. 12]. Если в 1952 г. они были приняты из Астраханской области «с убытком в сумме 1,9 млн рублей и просроченной задолженностью Госбанку в сумме 5,8 млн рублей», то следующий финансово-хозяйственный год закончили с прибылью в сумме 38,2 тыс. рублей. Предполагалось, что в 1954 г. они должны были получить не менее 5,5 млн рублей прибыли. С целью дальнейшего «наиболее правильного использования громадной территории Степного района» перед совхозами овцеводческого треста была поставлена задача в ближайшие дватри года довести поголовье тонкорунных овец не менее чем в 100 голов на каждые 100 гектаров земли, а также «значительно расширить распашку целинных земель и вовлечь в сельскохозяйственный оборот с целью увеличения производства зерновых и кормовых» [РГАСПИ. Ф. 556. Оп. 14. Д. 11. Л. 12-13].

На основании изложенных фактов автор делал главный вывод о том, что «за последние два года совхозы и колхозы Степного района, находясь в административных границах Ставропольского края, добились значительного экономического роста». От лица руководства Ставропольского края А. И. Васьков писал: «Считаем, что передача Степного района в административное подчинение Астраханской области экономически является нецелесообразной» [РГАСПИ. Ф. 556. ОП. 14. Д. 11. Л. 13].
Таким образом, в рассматриваемом документе не только доказывались успехи в развитии Степного района в составе Ставропольского края, но и их взаимосвязь с действиями краевого руководства и советского правительства, в первую очередь, с решениями сентябрьского пленума ЦК КПСС (1953 г.), рассмотревшего вопрос «О мерах по дальнейшему развитию сельского хозяйства СССР». В справке упоминались меры по укреплению колхозов и совхозов кадрами и техникой, освоению целинных и залежных земель и другие актуальные задачи, поставленные партийным руководством. Но главный упор был сделан именно на подъеме тонкорунного овцеводства, о необходимости которого писали и астраханские руководители. Но, в отличие от их предложений, справка содержала конкретные данные о достигнутых успехах в Ставропольском крае в данном вопросе.

Для понимания механизма принятия решения несомненный интерес представляет еще один документ - справка начальника Главного управления животноводства и ветеринарии Министерства сельского хозяйства РСФСР, члена коллегии Министерства сельского хозяйства РСФСР П. А. Есаулова. Она была подготовлена в ответ на письмо, направленное Астраханским областным исполкомом в Совет Министров РСФСР. В справке отмечалось, что управление «не считает возможным поддержать» предложение Астраханского областного исполкома. Колхозы Сарпинского района Сталинградской области имели на начало текущего года 152 тыс. овец, из них только в четырех колхозах овцы зимовали на Черных землях Астраханской области. Всего было перегнано на Черные земли колхозами этого района в 1953 г. около 65 тыс. овец, или $40 \%$ от всего поголовья в районе [РГАСПИ. Ф. 556. Оп. 14. Д. 11. Л. 14].

Закрепленный за колхозами Сталинградской области участок государственного фонда «черные земли» в 40,6 тыс. гектаров находился в 250 км от основных земель Сарпинского района. П. А. Есаулов отмечал, что по природным и экономическим условиям этот район больше тяготел к Сталинградской области, чем к Астраханской, а районный центр - село Садовое - находился в 137 км от Сталинграда и имел более удобную с ним связь, чем с Астраханью, рассто- 
яние до которой составляло более 300 км. Колхозы Апанасенковского района Ставропольского края имели на 1 января 1954 г. 250 тыс. голов тонкорунных овец, колхозы Арзгирского района - 200 тыс. тонкорунных овец. Колхозы Степного района на ту же дату имели 167 тыс. тонкорунных овец. В колхозах Астраханской области на 1 января 1954 г. имелось 686 тыс. овец, но всего лишь $12 \%$ из них являлись тонкорунными [РГАСПИ. Ф. 556. Оп. 14. Д. 11. Л. 14]. В результате «по направлению животноводства и природно-экономическим условиям» колхозы Степного района признавались близкими к колхозам Ставропольского края, в связи с чем П. А. Есаулов не видел оснований «вновь пересматривать вопрос об изменении границ Астраханской области» [РГАСПИ. Ф. 556. Оп. 14. Д. 11. Л. 15].

Итоговый документ по данному вопросу был подготовлен для ЦК КПСС 4 июня 1954 г. заведующим отделом партийных, профсоюзных и комсомольских органов ЦК КПСС Е. И. Громовым и заведующим сельскохозяйственным отделом ЦК КПСС по РСФСР В. П. Мыларщиковым [Справочник по истории]. В представленной ими записке обобщались все вышеизложенные аргументы и позиции сторон. Сообщалось, что Ставропольский крайком и Сталинградский обком партии категорически возражали «против передачи Степновского и Сарпинского районов в состав Астраханской области и доводы Астраханского обкома партии и облисполкома считают неосновательными» [РГАСПИ. Ф. 556. Оп. 14. Д. 11. Л. 16].

Передача Степновского района из Астраханской области объяснялась тем, что «Ставропольский край является основным районом ценного тонкорунного овцеводства, и для его дальнейшего развития необходимо было увеличить пастбищные угодья». Это решение получало положительную оценку, поскольку позволило увеличить пастбищные угодья в Ставропольском крае с 2 до 3,6 млн гектаров. Указывалось на то, что Степновский район в экономическом и географическом положении тяготел к Ставропольскому краю: «Направление развития сельского хозяйства района родственно с близлежащими районами Ставропольского края. В этом районе в основном развивается тонкорунное овцеводство, в то время как в Астраханской области тон- корунные овцы составляют лишь $12 \%$ от общего поголовья овец» [РГАСПИ. Ф. 556. Оп. 14. Д. 11. Л. 17].

До передачи в состав Ставропольского края колхозы и совхозы Степновского района занимались в основном разведением мясомолочного скота и каракульских овец. Повторяя данные, приведенные А. И. Васьковым, Е. И. Громов и В. П. Мыларщиков отмечали успехи в развитии хозяйственной и социальной инфраструктуры Степновского района, значительное расширение посевных площадей под зерновые и кормовые культуры, «с тем расчетом, чтобы в ближайшее время полностью обеспечить животноводство кормами и еще выше поднять доходность земель Степновского района», превращение совхозов из убыточных в рентабельные хозяйства [РГАСПИ. Ф. 556. Оп. 14. Д. 11. Л. 16-17].

Далее указывалось, что и Сарпинский район, расположенный от Сталинграда на расстоянии 140 км, а от Астрахани - более чем 300 км, по своим природным и экономическим условиям более тяготел к Сталинградской области, а не к Астраханской. Доводы Астраханского обкома партии о том, что район не обеспечен кормами, признавались неверными: «Это видно хотя бы из того, что в прошедшую зиму некоторые скотоводческие совхозы Астраханской области, расположенные вблизи Сарпинского района, получали помощь в кормах из этого района» [РГАСПИ. Ф. 556. Оп. 14. Д. 11. Л. 17-18].

Авторы отмечали, что на 1 мая 1954 г. Астраханская область имела 749 тыс. овец, Ставропольский край - 3516 тыс. овец, Сталинградская область - 1445 тыс. овец. При этом в Астраханской области на каждую овцу приходилось около 1,5 гектара пастбищных угодий, в то время как в Ставропольском крае, включая Степновский район, - 1,1 гектара. Е. И. Громов и В. П. Мыларщиков указывали, что пастбищные угодья Астраханской области позволяли ей увеличить поголовье тонкорунных овец в 1,5-2 раза, а астраханские организации могли принять необходимые меры по использованию возможностей для заготовки сена в Волго-Ахтубинской пойме: «Для этого нет необходимости присоединять к области Степновский и Сарпинский районы» [РГАСПИ. Ф. 556. Оп. 14. Д. 11. Л. 18]. 
Кроме того, отмечалось, что Совет Министров РСФСР разрабатывал мероприятия по улучшению использования земель Волго-Ахтубинской поймы для выращивания овоще-бахчевых культур. Подчеркивалось, что Сарпинский райком партии Сталинградской области и Степновский райком партии Ставропольского края также считали «экономически и хозяйственно нецелесообразным передачу их районов в Астраханскую область» [РГАСПИ. Ф. 556. Оп. 14. Д. 11. Л. 18].

Вывод авторов записки был очевиден: «Считаем нецелесообразным передавать Степновский и Сарпинский районы в состав Астраханской области. Просим согласия сообщить секретарю Астраханского обкома КПСС т. Ганенко, что предложение обкома партии и облисполкома о передаче в состав Астраханской области Степновского района Ставропольского края и Сарпинского района Сталинградской области является неприемлемым» [РГАСПИ. Ф. 556. Оп. 14. Д. 11. Л. 18].

В резолюции, датированной 9 июня 1954 г., сообщалось о том, что Астраханскому обкому КПСС (второму секретарю обкома А. А. Шапошникову) «ответ сообщен» [РГАСПИ. Ф. 556. Оп. 14. Д. 11. Л. 16].

\section{Результаты}

Разногласия между Астраханской областью, с одной стороны, и Сталинградской областью и Ставропольским краем, с другой стороны, по поводу Сарпинского и Степновского районов стали ярким примером территориальных споров различной степени остроты и напряженности между отдельными национально-государственными и административно-территориальными образованиями в СССР. Общие причины данных разногласий, как и многих других, связаны с активными административно-территориальными преобразованиями советского периода, в первую очередь, с ликвидацией национальных автономий ряда народов СССР в годы Великой Отечественной войны. В то же время в каждом случае конкретный спор всегда был вызван своими собственными причинами, требующими специального изучения.

Один из главных периодов обострения территориальных претензий национально-государственных и административно-территориальных образований на юге страны пришелся на период после смерти И. В. Сталина и был вызван изменениями в политическом руководстве страны. Например, Кабардинский обком КПСС в 19531954 гг. дважды ставил перед ЦК КПСС и Советом Министров СССР вопрос о возвращении северо-восточной части Курпского района, переданной в 1944 г. Северо-Осетинской АССР [РГАСПИ. Ф. 556. Оп. 14. Д. 11. Л. 15-17].

Грозненский обком КПСС обратился 12 июня 1954 г. с просьбой в ЦК КПСС о возвращении колхозам Сунженского района пахотных земель, переданных в январе 1949 г. Северо-Осетинской АССР [РГАСПИ. Ф. 556. Оп. 14. Д. 11. Л. 23-26]. Однако во всех случаях руководство Северо-Осетинского обкома КПСС резко возражало [РГАСПИ. Ф. 556. Оп. 14. Д. 11. Л. 18-20, 31], и советское руководство сохраняло статус-кво. Реакция советского руководства на предложения, исходившие в 1953-1955 гг. от национально-государственных и административно-территориальных образований об изменении их границ, показывает, что оно в это время было достаточно осторожным в данных вопросах. При возникновении территориальных претензий со стороны отдельных субъектов выяснялась позиция других заинтересованных сторон. Это создавало впечатление новой атмосферы принятия управленческих решений, при которой учитывалось мнение региональных властей по сравнению с предшествующим периодом [Хлынина, Кринко, Урушадзе 2012: 245].

Нельзя не видеть определенное сходство в приведенных выше примерах с рассматриваемой ситуацией. В то же время она имела и свою специфику, поскольку в данном случае причины сводились исключительно к хозяйственным факторам и не имели национальной или политической подоплеки. Инициаторами обсуждения вопроса о территориальных изменениях выступили астраханские руководители, сравнительно недавно занявшие свои должности. Первый секретарь обкома И. П. Ганенко только в январе 1954 г. переехал в Астрахань из Москвы, где проработал два года в отделе партийных, профсоюзных и комсомольских органов ЦК КПСС, причем последний год - заведующим сектором (здесь и далее см.: [Справочник по истории]). 
П. С. Кузьмин стал председателем облисполкома в предыдущем 1953 г., но перед этим еще год проработал заместителем председателя облисполкома. Его предшественник на посту председателя облисполкома А. А. Шапошников почти всю жизнь проработал в Астрахани, в рассматриваемый период - в должности второго секретаря обкома партии. Можно предположить, что деятельный И. П. Ганенко, с солидным фронтовым опытом, оказавшись на новой должности, искал способы подъема хозяйства Астраханской области и рассчитывал на поддержку своих инициатив в ЦК КПСС, где у него, вероятно, оставались связи. Однако и ставропольские руководители могли рассчитывать на нее не в меньшей степени уже потому, что одним из секретарей ЦК КПСС являлся М. А. Суслов, руководивший

\section{Источники \\ Aрхивные}

ГАВО - Государственный архив Волгоградской области

РГАСПИ — Российский государственный архив социально-политической истории

\section{Сборник документов}

Государственное строительство $2009-$ Государственное строительство Калмыкии. XVII-XXI вв. Сб. док. и мат-лов. Элиста: ЗАОр «НПП «Джангар», 2009. 399 с.

\section{Литература}

Астраханская область 1984 - Астраханская область: справочник по административно-территориальному делению (1918-1983 гг.). Волгоград: Нижне-Волжское кн. изд-во, $1984.335 \mathrm{c}$.

История административно-территориального 2009 - История административно-территориального деления Волгоградской (Сталинградской) области, 1936-2007 г.: справочник. Т. 3. Волгоград: Волгоградское науч. изд-во, 2009. 757 с.

История Кабардино-Балкарской 1967 - История Кабардино-Балкарской АССР с древнейших времен до наших дней. Т. 2: История Кабардино-Балкарской АССР с Великой Октябрьской социалистической революции до наших дней. М.: Наука, 1967. 439 с.

История Калмыкии 2009 - История Калмыкии с древнейших времен до наших дней. В 3 т. T. II. Элиста: Герел, 2009. 840 c.
Орджоникидзевским (Ставропольским) крайкомом ВКП(б) в 1939-1944 гг. Анализируемые документы свидетельствуют о том, что позиция руководства Астраханской области оказалась менее аргументированной, чем у его оппонентов. Именно это и стало главной причиной отказа советского руководства от передачи в Астраханскую область Сарпинского и Степного районов.

Новые изменения в административно-территориальной системе региона произошли в связи с реабилитацией калмыков и восстановлением их национальной автономии. В 1957 г. была создана Калмыцкая автономная область в составе Ставропольского края, на следующий год преобразованная в Калмыцкую АССР. В ее состав без каких-либо разногласий были включены Сарпинский и Степной районы.

История Чечни 2008 - История Чечни с древнейших времен до наших дней. Т. II. История Чечни XX и начала XXI веков. Грозный: Книжное изд-во, 2008. 832 с.

Калмыцкая АССР 1984 - Калмыцкая АССР. Административно-территориальное деление: 1918-1982. Справочник. Элиста: Калм. кн. изд-во, 1984. 125 с.

Кропачев, Кринко 2019 - Кропачев С. Я., Кринко Е. Ф. Потери населения СССР в 19371945 гг.: масштабы и формы. Отечественная историография. М.; Берлин: Директ-Медиа, 2019. 392 c.

Очерки истории Калмыцкой 1970 - Очерки истории Калмыцкой АССР. Т. 2. Эпоха социализма. М.: Наука, 1970. 432 с.

Очерки истории Карачаево-Черкесии 1972 Очерки истории Карачаево-Черкесии. Т. 2: Советский период. Черкесск: Карачаево-Черкесское отделение Ставропольского кн. изд-ва, 1972. 448 с.

Очерки истории Чечено-Ингушской 1972 Очерки истории Чечено-Ингушской АССР. Т. 2: 1917-1970. Грозный: Чечено-Ингушское кн. изд-во, 1972. 359 с.

РСФСР 1947 - РСФСР. Административно-территориальное деление на 1 января 1948 г. М.: Известия Советов депутатов трудящихся СССР, 1947. 496 с.

РСФСР 1955 - РСФСР. Административно-территориальное деление на 1 января 1955 г. М.: Известия Советов депутатов трудящихся СССР, 1955. 440 с. 
Справочник по истории - Справочник по истории Коммунистической партии и Советского Союза 1898-1991 [электронный ресурс] // URL: http://www.knowbysight.info/index.asp (дата обращения: 23.04.2020).

Степанов 2010 - Степанов М. Г. Этнические депортации в СССР: проблемы российской историографии. Абакан: Хакасский гос. ун-т им. Н. Ф. Катанова, 2010. 112 с.

Территориальные преобразования 1976 - Тер-

\section{Sources}

Archives

State Archive of Volgograd Oblast.

Russian State Archive of Socio-Political History.

\section{Collected Documents}

[Kalmykia. State-Building: $17^{\text {th }}-21^{\text {st }}$ Centuries]. Coll. documents and materials. Elista: Dzhangar, 2009. 399 p. (In Russ.)

\section{References}

[A Handbook on the History of the Communist Party and the Soviet Union 1898-1991]. URL: http:// www.knowbysight.info/index.asp (accessed April 23 2020).

[Astrakhan Oblast: Handbook of Administrative Geography, 1918-1983]. Volgograd: Lower Volga Book Publ., 1984. 335 p. (In Russ.)

[Chechen-Ingush ASSR: Historical Essays]. Grozny: Chechen-Ingush Book Publ., 1972. Vol. 2: 1917-1970. 359 p. (In Russ.)

[Communist Party and Soviet Union: Historical Handbook, 1898-1991]. Available at: http:// www.knowbysight.info/index.asp (accessed: April 23, 2020). (In Russ.)

[History of Chechnya: from Earliest Times to the Present Days]. Vol. II: Chechnya in the $20^{\text {th }}$ and Early $21^{\text {st }}$ Centuries. Grozny: (Regional) Book Publ., 2008. 832 p. (In Russ.)

[History of Kalmykia: from Earliest Times to the Present Days]. In 3 vols. Vol. II. Elista: Gerel, 2009. 840 p. (In Russ.)

[History of the Kabardino-Balkarian Republic: from Earliest Times to the Present Days]. Vol. 2: Kabardino-Balkarian ASSR, from the Great October Socialist Revolution to the Present Days. Moscow: Nauka, 1967. 439 p. (In Russ.) риториальные преобразования и переименования населенных пунктов Ростовской области за 1937-1970 гг. Справочник. Р/н/Д.: Кн.изд-во, 1976. 272 с.

Хлынина, Кринко, Урушадзе 2012 - Хльнина Т. П., Кринко Е. Ф., Урушадзе А. Т. Российский Северный Кавказ: исторический опыт управления и формирования границ региона. Ростов н/Д: Изд-во ЮНЦ РАН, 2012. $272 \mathrm{c}$.

[Kalmyk ASSR: Administrative Geography, 19181982]. Reference book. Elista: Kalmyk Book Publ., 1984. 125 p. (In Russ.)

[Kalmyk ASSR: Historical Essays]. Vol. 2: Socialist Era. Moscow: Nauka, 1970. 432 p. (In Russ.)

[Karachay-Cherkessia: Historical Essays]. Vol. 2: Soviet Era. Cherkessk: Karachay-Cherkess Branch of Stavropol Book Publ., 1972. 448 p. (In Russ.)

[Rostov Oblast: Territorial Changes and Renaming of Localities, 1937-1970]. Reference book. Rostov-on-Don: (Regional) Book Publ., 1976. 272 p. (In Russ.)

[RSFSR: Administrative Structure as on January 1, 1948]. Moscow: Izvestia (Reports) of Soviets of Workers' Deputies, 1947. 496 p. (In Russ.)

[RSFSR: Administrative Structure as on January 1, 1955]. Moscow: Izvestia (Reports) of Soviets of Workers' Deputies, 1955. 440 p. (In Russ.)

[Volgograd (Stalingrad) Oblast: History of Administrative Geography, 1936-2007]. Reference book. Vol. 3. Volgograd: Volgograd Science Publ., 2009. 757 p. (In Russ.)

Khlynina T. P., Krinko E. F., Urushadze A. T. [Russian North Caucasus: Historical Experience of Administering and Shaping Internal Borders]. Rostov-on-Don: Southern Scientific Center of RAS, 2012. 272 p. (In Russ.)

Kropachev S. Ya., Krinko E. F. [The USSR: Scopes and Forms of 1937-1945 Population Losses. Domestic Historiography]. Moscow; Berlin: Direkt-Media, 2019. 392 p. (In Russ.)

Stepanov M. G. [Ethnic Deportations in the USSR: Issues of Russian Historiography]. Abakan: Katanov Khakas State University, 2010. 112 p. (In Russ.) 